\title{
Gravity Structure around Mt. Pandan, Madiun, East Java, Indonesia and Its Relationship to 2016 Seismic Activity
}

https://doi.org/10.1515/geo-2018-0069

Received November 12, 2017; accepted November 17, 2018

Abstract: Java Island is part of the island arc influenced by subducting Indo-Australian beneath Eurasian tectonic plates, therefore there is high seismic activity and an active volcanic chain trending East-West. One of the volcanoes in Java Island is Mt. Pandan, northern part of Madiun, East Java region, which is known as one of the dormant volcano in the region. According to the list of volcanoes in Indonesia Mt. Pandan is not classified as an active volcano. The previous studies mentioned that Mt. Pandan is a modern volcano which is located in the Kendeng zone. On June 25, 2015, there was felt earthquake (M 4.2) causing several houses damaged around Mt. Pandan as reported by Agency for Meteorology, Climatology, Geophysics (BMKG), Indonesia and then in February 2016, more than twenty small earthquakes $(\mathrm{M}<4)$ occurred again in the area. In order to understand the structure beneath Mt. Pandan, we have conducted gravity measurement and seismicity analysis through hypocenter relocation. Our results show prominent low gravity and density anomalies by forward modeling derived from residual anomaly around Mt. Pandan area. The clusters of small earthquakes appear at depths of less than $30 \mathrm{~km}$ beneath Mt. Pandan. The selected focal mechanism of the event in the area is leftlateral faulting in the north and oblique dominant thrust in the south of Mt. Pandan. Some indications related to submagmatic activities such as hot springs and warm ground is found. Our interpretation is this phenomenon may be related to tectonic and magmatic activities. On the other hand, it confirms also that Mt. Pandan is probably a modern volcanic center.

Keywords: Mt. Pandan, small earthquake, gravity structure, magma, tectonic

\footnotetext{
*Corresponding Author: D. Santoso: Applied and Exploration Geophysics Research Group, Faculty of Mining and Petroleum Engineering, Institut Teknologi Bandung, Bandung, Indonesia, E-mail: dsantoso78@yahoo.com or dsantoso@gf.itb.ac.id
}

\section{Introduction}

Mt. Pandan of 897 meters high is a relatively small mountain in East Java area, Indonesia. It is located in the approximately $40 \mathrm{~km}$ northeast of Madiun city. This volcano is not listed as active volcanoes in Indonesia. Java Island is located in the southern part of Indonesia Island arc, therefore this region contains of volcanic chain. An EastWest recent active volcanic chain was built in the region. On the southern part of Eurasian plate margin, Java Island is subducted by Indo-Australian plate. Java trench is the elongated location where the subduction has occurred. The subduction started from the age of middle Eocene to present day [1]. Then, Java is developed as a volcanic island contains the active volcanism since the early Cainozoic. The modern Sunda Arc volcanoes are distributed along the island. A second older arc of Eocene to Miocene volcanoes in East Java formed the Southern Mountain [2]. Sunda Arc volcanoes are a modern volcanic chain in East Java area built mainly in the Kendeng zone. One of the active volcanic centres in the area is Mt. Wilis. As a volcanic centre, this volcano is defined as one of modern volcanic centers [3] (Figure 1).

Mt. Pandan is located northern of Mt. Wilis (Figure 1) and has a conical morphology which also defined it as a modern volcanic center [3]. The Center for Volcanology and Geological Hazard Mitigation, Bandung, Indone-

E.J. Wahyudi, W.G.A. Kadir, S. Alawiyah, W.W. Parnadi: Applied and Exploration Geophysics Research Group, Faculty of Mining and Petroleum Engineering, Institut Teknologi Bandung, Bandung, Indonesia

A. D. Nugraha: Global Geophysics Research Group, Faculty of Mining and Petroleum Engineering, Institut Teknologi Bandung, Bandung, Indonesia

P. Supendi: Geophysical Engineering Study Program, Faculty of Mining and Petroleum Engineering, Institut Teknologi Bandung, Bandung, Indonesia and Agency for Meteorology, Climatology, and Geophysics (BMKG), Bandung, Indonesia 


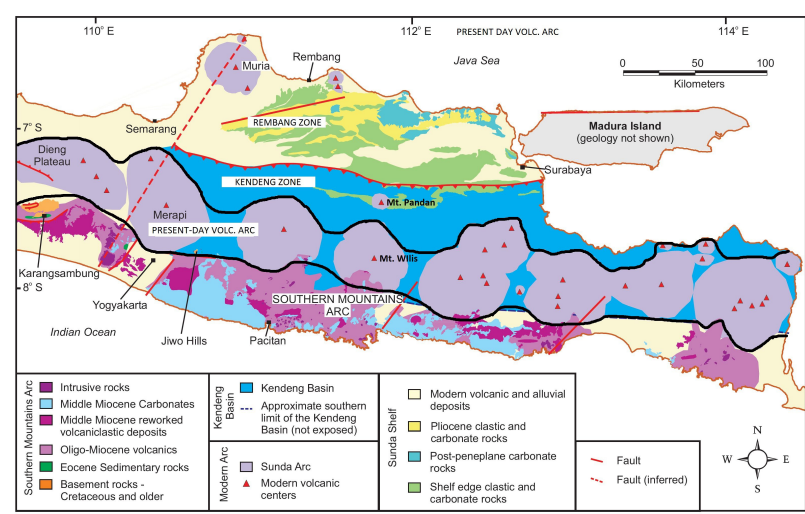

Figure 1: Simplified geological map of East Java area and its Tectonostratigraphy (modified from [3]).

sia (CVGHM) defined that Mt. Pandan is a dormant volcano that has a relatively little conical shape. The height of this mountain approximately 300 meters compare to the surrounding area. Some recent small earthquakes were recorded in the area. On the other hand, there are some indications related to submagmatic activities such as several hot springs and warm ground which is found as dried vegetation in the area. The recent seismic hazard map of Indonesia [4] showed there is an active fault that we called Kendeng Thrust fault zone lies which striking East-West in the northern part of Mt. Pandan area. The previous GPS study of Koulali et al. [5] showed a kinematic model of the subducting of the Indo-Australian plate beneath the Sunda Block, including a slip partitioning between the Java Trench and an East-West left lateral fault along Java region. Whereas, the main convergence motion mainly are accommodated by the Java megathrust and minor parallel motion accommodated along the Kendeng and Baribis Thrusts. The previous study of ambient noise tomography in Central and East Java areas [6, 7] exhibited very low Vs structure in the Kendeng Basin which is associated with thickness of sediment layer. The contrast velocity features were observed around the Rembang High, northern part of Kendeng Basin and the very low group velocities were also observed around active volcanoes [7].

The seismicity activity in East Java area is relatively high due to the Java subduction zone and inland active faults [8-10]. The events clearly reveal Wadati-Benioff zone geometry at the Java trench and back thrusts in the south of East Java area [10].

Therefore, there are some possibilities as source of occurrence of small earthquakes in this region including (i) it may be related to an activation of Kendeng Thrust fault in this segment, (ii) it may be related to magmatic processes, and (iii) it may be related to combination of both two-geological conditions (tectonic and magmatic). In this study, we attempt to understand the relationship between recent small earthquakes activities and subsurface structure beneath Mt. Pandan derived from gravity data. Analysis of small earthquake is also very important to determine of the level of hazard to support for seismic hazard analysis in the region [11].

\section{Mt. Pandan as one of the volcanic geological feature in East Java, Indonesia}

The previous study of Van Bemmelen has divided Java Island into some regions physiographically [12]. This zonation also reflects structural and stratigraphical features or tectonostratigraphy. A modification of tectonostratigraphy zonation in East Java area was carried out by Smyth et al. [3]. It was divided into four areas from south to north (Figure 1), as follows: (i) Southern Mountain Zone. This zone consists of the Eocene-Miocene volcanic arc which is built on Mesozoic basement. The sediments deposits include siliciclastic, volcaniclastic, volcanic and carbonate rocks. These rocks generally have dipping uniformly to the south, (ii) Present-day Volcanic Arc and this volcanic chain activated since the Late Miocene age, (iii) Kendeng Zone which is known as the main EoceneMiocene depocenter in East Java area. This zone contains thick sequences of volcanogenic and pelagic sedimentary deposits. It is now dissected by East-West trending thrust belt, and (iv) Rembang Zone which is consists of the Eocene-Pliocene sedimentary sequence includes shelfedge deposits such as shallow marine clastic sediments and extensive carbonates. This zone contains of a structure called as Rembang High which is develop by one major ENE-WSW fault-bounded high and some east-west orientated folds.

Simplified geological map of East Java including its tectonostratigraphic zonation location of Mt. Pandan and its surrounding area can be seen in Figure 1. The Kendeng Thrust fault directed East-West in the region as the boundary between Kendeng and Rembang zones are an important structural feature related to Mt. Pandan. 


\section{Hypocenter relocation of recent small earthquakes around $\mathrm{Mt}$. Pandan, Madiun, East Java area}

As informed by Agency for Meteorology, Climatology, Geophysics, Indonesia (BMKG), there was an earthquake occurred in Madiun, East Java, Indonesia, on June 25, 2015 with a depth of $\sim 10 \mathrm{~km}$ and magnitude of 4.2 close to Mt. Pandan. The previous study of Nugraha et al. [13] showed the focal mechanism of this event was strike-slip mechanism and focus depth of $\sim 14.8 \mathrm{~km}$ which may be related to local fault in east of Madiun city. Later on, small earthquake sequences occurred again in February 2016 around Mt. Pandan area. In this study, we have re-picked of Pand S-wave arrival times (Figure 2) from 29 local small events with depth less than $30 \mathrm{~km}$ around Mt. Pandan, Madiun, East Java region that were recorded by BMKG seismographs regional network for time period of February 2016 (Figure 3). We used Seisgram2K software [14] to determine onset of P-and S-wave arrival times. Hypoellipse code was applied to determine hypocenter location of the events [15]. We used HypoDD program [16] to running the double-difference method [17] for hypocenter relocation using 1D seismic velocitty model [18]. We selected events with relatively high signal to noise ratio for focal mechanism analysis. We used ISOLA package for performing moment tensor inversion [19]. We inverted for full moment tensors from the displacement records from at least three local stations. The stations at a small epicentral distance were chosen. The observed waveforms were pre-processed by high-pass filtering with a corner frequency of $0.075 \mathrm{~Hz}$ to $0.16 \mathrm{~Hz}$. Comparison of the correlation coefficient between the observed and the best fitting synthetic seismograms is more important for the success of the inversion.

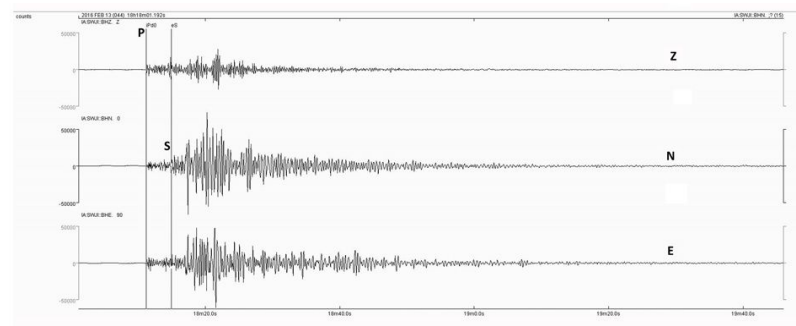

Figure 2: Example of 3-C seismogram for events occurred on February 13, 2016 recorded at SWJI-BMKG station. Black line indicates picked of P-and S-wave arrival times.

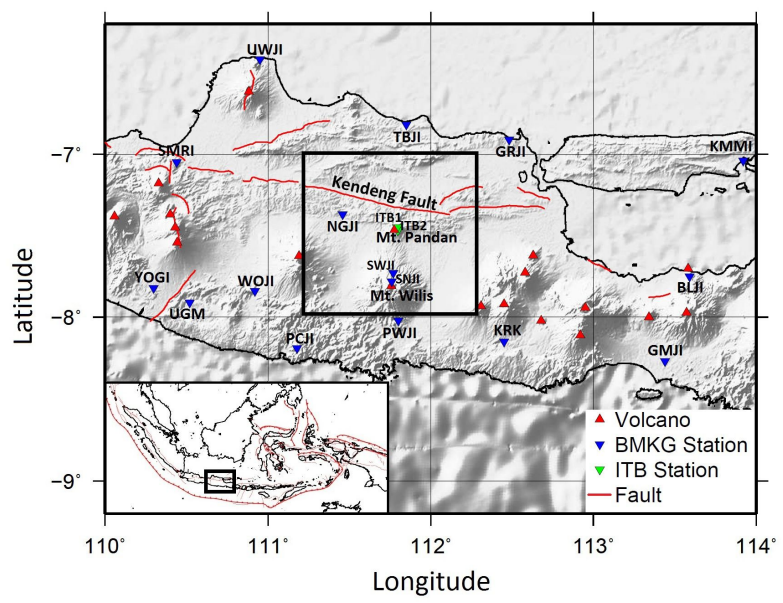

Figure 3: Distribution of BMKG seismograph networks (reverse blue triangles with labels), ITB stations (reverse green triangles), volcanoes (red triangles), and fault lines (red line) from Irsyam et al. [4] in East Java region. Black box is a focus of study area including Mt. Pandan and Mt.Wilis areas.
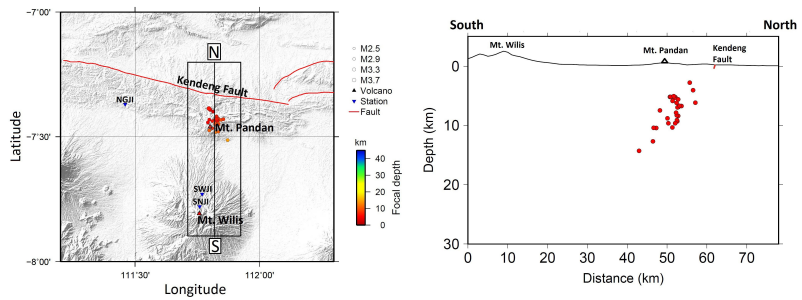

Figure 4: (left) Distribution of relocated small events obtained in this study around Mt. Pandan, Madiun, East Java region. (right) The vertical cross-section of North-South passing through Kendeng Thrust fault, Mt. Pandan, and Mt. Wilis, respectively.

Our results show the relocated of small earthquakes $(M<4)$ are concentrated around Mt. Pandan with focus depths of less than $10 \mathrm{~km}$ which have dipping to the south direction as shown in Figure 4. The main causing of these small events sequences are still intriguing to be investigated. The Kendeng Thrust fault is located in the northern part of Mt. Pandan, where the active volcano of Mt. Wilis is located in southern part of these events cluster. This situation leads to whether it is related to activities of Kendeng Thrust fault or volcano/sub magmatic or combination magmatic and tectonic. We have attempted to analyze of focal mechanism from selected small events in the area. As a results show the source mechanism of events are mainly left lateral and oblique-thrust faults in the north and south of Mt. Pandan area, respectively (Figure 5).

We (Geophysical Engineering, Faculty of Mining and Petroleum Engineering, Institut Teknologi Bandung, Indonesia) have deployed 2 temporary seismographs station 


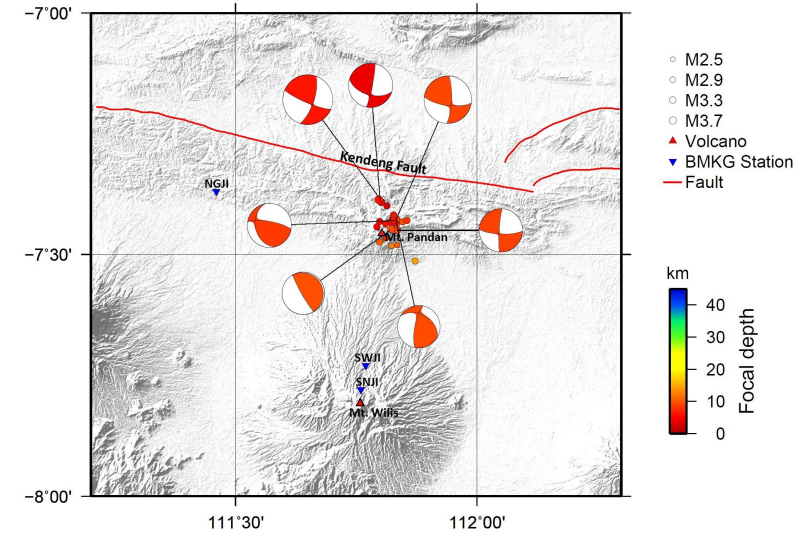

Figure 5: Selected of focal mechanism of small events around Mt. Pandan, Madiun, East Java region from this study.

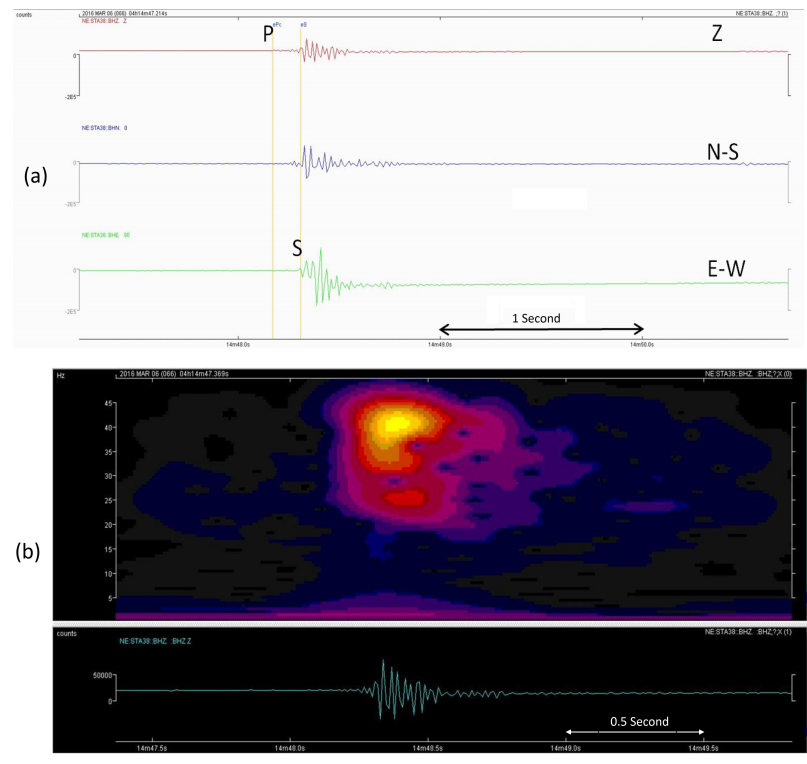

Figure 6: (a) An example of three component seismogram for small earthquake that occurred on March 6, 2016 (04:14 UTC) recorded by ITB temporary station around Mt. Pandan and (b) spectrogram for vertical seismogram component.

(here and after we called ITB Station) around Mt. Pandan, Madiun, East Java area (Figure 2) in March to May, 2016. The objective is to characterize the waveform signal of these small events sequences, however, the events are not so frequently observed at this time periods. We observed prominent shallow small event which has characteristic of very short duration ( 1 second), moderate high frequency content of signal $(\sim 20-45 \mathrm{~Hz})$ and very short time difference between S-and P-arrival times ( $<0.3$ seconds) as shown in Figure 6. A clear waveform signal and separation between $P$ wave and $S$ wave arrival usually indicate a tectonic earthquake.

\section{Gravity Survey around Mt. Pandan, Madiun, East Java area}

We also conducted gravity survey around Mt. Pandan in June 2016 [20] as comparison with seismicity analysis. The goal of this study is to delineate subsurface structure of Mt. Pandan and its relationship with recent small earthquakes sequence. The measurement was carried out by using Gravimeter Scintrex CG-5 (SN-815). The obtained Complete Bouguer Anomaly and Residual Anomaly maps are shown in Figure 7 . The gravity survey shows some interesting results including the low Complete Bouguer Anomaly and low Residual Anomaly are fairly clearly observed around Mt. Pandan (Figure 7). The 2D Nouth-South (N-S) cross-section of density anomaly calculated by forward modeling derived from Residual Anomaly is shown in Figure 8. Accordingly, it shows fairly clearly low density value beneath Mt. Pandan. The low density value continues from the north to south of beneath Mt. Pandan.

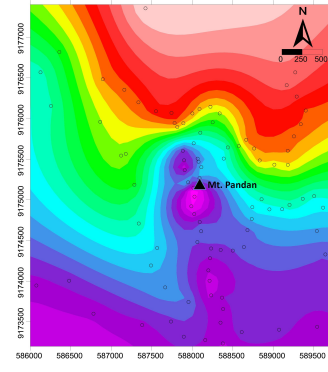

(a)

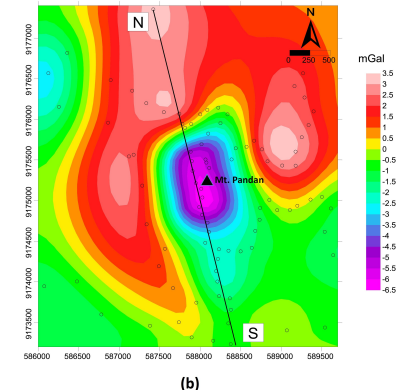

Figure 7: (a) Complete Bouguer Anomaly and (b) Residual Anomaly Maps around Mt. Pandan area from our previous study [20]. Red and blue colors stand for high and low anomaly, respectively. Black line indicates location of N-S for density forward modelling. Black circles are gravity measurement station.

\section{Discussion}

Seismogram signal of small earthquakes around Mt. Pandan area show clear onset P-and S-wave arrival times and moderate frequency content indicated that these events were originated by tectonic activity. The focal mechanism of these events mainly strike slip and oblique thrust faults. Where, the gravity anomalies show an indication of low density value beneath Mt. Pandan area. These features may be related to weak zone, hot materials or magma source. The 2D geological interpretation based on gravity 


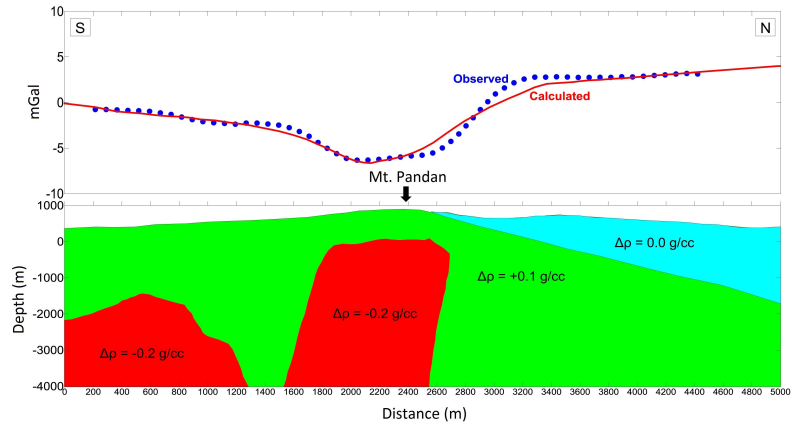

Figure 8: Vertical cross section of N-S for density forward modeling shows derived from Residual Anomaly beneath Mt. Pandan modified from our previous study [20].

model is shown in Figure 9. Our interpretation is that low density anomaly may be related to hot material or magma body. This low density value also dipping to the south of Mt. Pandan toward Mt. Wilis. The submagmatic activity including hot springs and warm ground are also found around Mt. Pandan area. These features indicate an existing of magmatic activity beneath the area. The previous study of regional seismicity from Nugraha et al. [10] shows clearly intra slab earthquake of Indo-Australia Plate subducts beneath Sunda Arc in East Java area (Figure 10). The cluster of earthquakes also exhibit beneath Mt. Wilis and Mt. Pandan areas. Some events also appear around the Kendeng Thrust fault. Mt. Pandan area is located in complex and active geological setting. We found low density body anomaly beneath Mt. Pandan from gravity survey which probably related to magma source or hot material along with small earthquakes sequences related to the tectonic activities. Since the Indo - Australian Plate subducted beneath Eurasian Plate in East Java region, the Java Trough was developed followed by accretion ridge, fore arc basin, Southern Mountain region, modern volcanic arc, Kendeng Basin and Rembang zone. As part of modern volcanic arc, subsurface geological structure of Mt. Wilis and Mt. Pandan in East Java based on gravity interpretation could be illustrated as the origin of magma source (Figure 11).

The molten magma generated from the subduction process is moving upward produces Present Day Volcanic Arc on the island of Java. Mt. Wilis and Mt. Pandan are volcanoes as part of this volcanic arc which has magma source derived from the subduction zone processes. The main magma chamber beneath Mt. Willis and some magma is flowing toward north that forms Mt. Pandan. Submagmatic activities manifestation around Mt. Pandan including hot springs and hot soil showed an indication of heat source beneath the surface. These phenom-

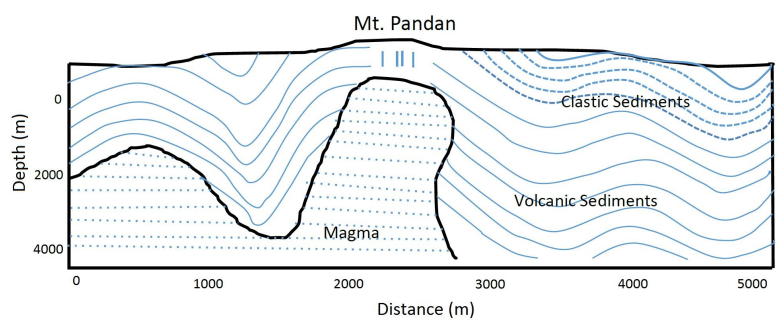

Figure 9: Schematic diagram of 2D geological section derived from gravity forward modelling beneath Mt. Pandan showing an indication upwelling Magma (?) as a low density surrounded by volcanic and sedimentary deposit in Kendeng Basin. Note: in the northern part of Kendeng zone is highly folded due to Kendeng Thrust fault.
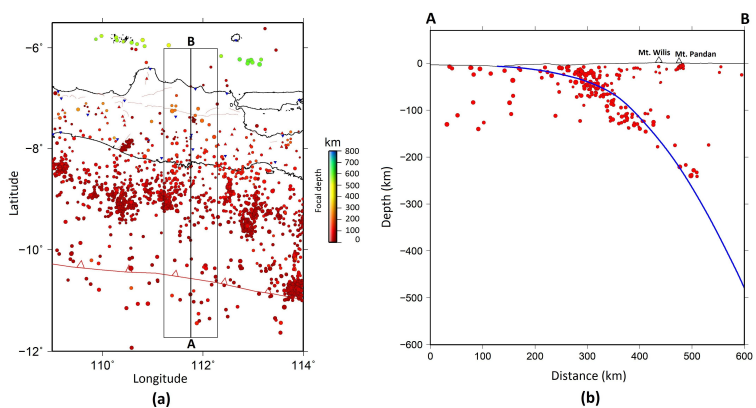

Figure 10: (a) Distribution of seismicity (color circles) in eastern of Java region from Nugraha et al. [10]. (b) Hypocenter distribution through Mt. Wilis and Mt. Pandan. Blue curve is Slab 1.0 model [21].

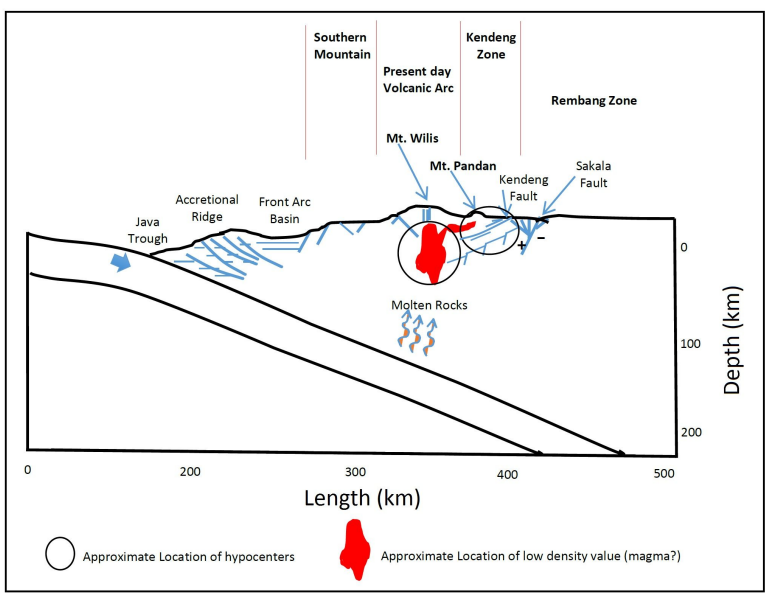

Figure 11: Tectonic model across north-south Java Island showing the position of Present Day Volcanic Arc where Mt. Wilis and Mt. Pandan as part of this arc as interpreted from gravity data. It indicates relationship to recent seismic activity. It is also noted the location of Kendeng Thrust fault has important role related to tectonic of north-east Java region (model modified from [2] and [22]).

ena support our gravity interpretation. Therefore, it could be explained that there is a possibility that both phenomena magmatic activity and Kendeng Thrust fault are re- 
lated to each other. It could be explained that subduction process produced the fault movement and at the same time also triggered the upwelling magma to the surface.

\section{Conclusions}

We have determined hypocenter location and focal mechanism analysis of recent small earthquakes and gravity survey around Mt. Pandan, Madiun, East Java, Indonesia. The small events have clear onset of $\mathrm{P}$ and $\mathrm{S}$ arrival times, strike-slip and oblique thrust faults type as indication of tectonic activity which probably related to Kendeng Thrust fault segment in the northern of Mt. Pandan. We also found low density body derived from gravity residual anomaly beneath Mt. Pandan and has dipping to the south direction of Mt. Pandan toward Mt. Wilis. Our interpretation is these features probably related to hot materials or magma source. The location of small events very close to Kendeng Thrust fault and Mt. Pandan suggest that tectonic and magmatic activities have strong relationship to each other in the area. However, for more details investigation and analysis, study of geology, geophysics and geodesy are needed to be conducted.

Acknowledgement: We thank Agency of Meteorology, Climatology, and Geophysics (BMKG) for waveform data used in this study. This study was supported in part by the KEMRISTEKDIKTI through the "Desentralisasi" research Grant 2016/2017 awarded to A.D.N. and in part by "P3MI ITB" Grant 2017 awarded to D.J.S.

\section{References}

[1] Hall R., Cenozoic geological and plate tectonic evolution of SE Asia and the SW Pacific: computer- based reconstructions, model and animations, J Asian Earth Sci., 20, 2002, 353-431.

[2] Simandjuntak T. O., Barber A. J., Contrasting tectonic styles in the Neogene orogenic belts of Indonesia, from Hall, R., Blundell, D., (eds.) Tectonic Evolution of Southeast Asia, Geol. Soc. London. Spec. Publ., 106, 1996, 185-201.

[3] Smyth, H.R., Hall R., Nichols, G.J., Cenozoic volcanic arc history of East Java, Indonesia: The stratigraphic record of eruptions on an active continental margin,in Draut, A.E., Clift, P.D., and Scholl, D.W., eds., Formation and Applications of the Sedimentary Record in Arc Collision Zones:Geological Society of America, Special Paper 436, 2008, p. 199-222, doi: 10.1130/2008.2436(10).

[4] Irsyam, M., Widiyantoro. S., Natawidjaja, D. H., Meilano, I., Rudyanto, A., Hidayati, S., Triyoso, W., Hanifa, N. R., Djarwadi, D., Faizal, L., Sunarjito, Earthquake sources and hazard map of
Indonesia, Research and Development Center, Minister for Public Works and Human Settlements, 2017, ISBN: 978-602-548901-3.

[5] Koulali A., McClusky S., Susilo S., Leonard Y., Cummins P., Tregoning P., Meilano I., Efendi J., Wijanarto A. B., The kinematics of crustal deformation in Java from GPS observation: Implication for fault slip partitioning, Earth. Planet. Sci. Lett., 458, 69-79, 2017, http://dx.doi.org/10.1016/j.epsl.2016.10.039.

[6] Martha A. A., Cummins P., Saygin E., Widiyantoro S., Masturyono, Imaging of upper crustal structure beneath East Java-Bali, Indonesia, with ambient noise tomography, Geosci. Lett., 4:14, 2017, doi:10.1186/s40562-017-0080-9.

[7] Zulfakriza, D., Saygin S., Cummins P. R., Widiyantoro S., Nugraha A. D., Lühr B.-G., Bodin T., Upper crustal structure of central Java, Indonesia, from transdimensional seismic ambient noise tomography, Geophys. J. Int., 197, 2014, 630-635, doi: 10.1093/gji/ggu016.

[8] C A.P., Nugraha A. D., Puspito N. T., Earthquake hypocenter relocation using double difference method in East Java and surrounding areas, AIP Conf. Proc., 1658, 030021, 2015, doi:10.1063/1.4915029.

[9] Nguyen N., Griffin J., Cipta A., Cummins P. R., Indonesia's Historical Earthquakes: Modelled examples for improving the national hazard map, Geoscience Australia, Canberra., 2015, http: //dx.doi.org/10.11636/Record.2015.023.

[10] Nugraha A.D., Shiddiqi A. A., Widiyantoro S., Clifford, Thurber, C. H., Pesiceck, J. D., Zhang, H., Wiyono, S. H., Ramdhan, M., Wandono, Irsyam, M., Hypocenter Relocation along the Sunda Arc in Indonesia, Using a 3D Seismic-Velocity Model, Seismol. Res. Lett., 89, 2018, 2A, 603-611, doi:10.1785/0220170107.

[11] Rundle J. B., Turcotte D. L., Donnellan A., Ludwig L. G., Luginbuhl M., Gong G., Nowcasting earthquakes, Earth and Space Science, 3, 2016, 480-486, doi:10.1002/2016EA000185.

[12] Van Bemmelen, R. W., The Geology of Indonesia, Govt. Printing Office, Nijhoff, The Hague, Netherland, 1949, $732 \mathrm{pp}$.

[13] Nugraha A. D., Supendi P., Shiddiqi H.S., Widiyantoro, S., Unexpected earthquake of June $25^{\text {th }}, 2015$ in Madiun, East Java, AIP Conf. Proc., 1730, 020001, 2016, doi: 10.1063/1.4947369.

[14] Lomax A., Michelini A., Mwpd: A Duration-Amplitude Procedure for Rapid Determination of Earthquake Magnitude and Tsunamigenic Potential from P Waveforms, Geophys. J. Int.,176, 2009, 200-214, doi:10.1111/j.1365-246X.2008.03974.x.

[15] Lahr, J. C., HYPOELLIPSE: A computer program for determining local earthquake hypocentral parameters, magnitude, and firstmotion pattern (Y2K Compliant Version). Open-file Report 99023, US Geological Survey, Golden, Colorado, paper and on-line editions, 1999, $112 \mathrm{pp}$.

[16] Waldhauser, F., HypoDD - A Program to Compute DoubleDifference Hypocenter Locations: United States Geological Survey, 2001.

[17] Waldhauser, F., Ellsworth, W.L., A double-difference earthquake location algorithm: Method and application to the Northern Hayward fault, California, B Seismol Soc Am, 90, 2000, 13531368.

[18] Koulakov, I., Bohm, M., Asch, G., Lühr, B.-G., Manzanares, A., Brotopuspito, K.S., Fauzi, Purbawinata, M.A., Puspito, N.T., Ratdomopurbo, A., Kopp, H., Rabbel, W.,Shevkunova, W., P and S velocity structure of the crust and the upper mantle beneath central Java from local tomography inversion, J. Geophys. Res., 112, 2007, B08310,doi:10.1029/2006JB004712. 
[19] Sokos E., Zahradník, J., ISOLA a Fortran Code and a Matlab GUI to Perform Multiple-Point Source Inversion of Seismic Data, Computers \& Geosciences, 34, 2008, 967-977.

[20] Santoso D., Wahyudi E. J., Alawiyah A., Nugraha A. D., Widiyantoro S., Kadir W. G. A., Supendi P., Wiyono S., Zulfakriza, Subsurface Structure Interpretation Beneath of Mt. Pandan Based on Gravity Data, IOP Conf. Series: Earth and Environmental Science., 62, 2017, 012038, doi: 10.1088/1755-1315/62/1/012038.
[21] Hayes, G. P., Wald D. J., Johnson R. L., Slab1.0: A threedimensional model of global subduction zone geometries, J. Geophys. Res., 117, 2012, B01302, doi: 10.1029/2011JB008524.

[22] Baumann, P., Depositional cycles on magmatic and back arcs: an example from Western Indonesia, Revue Inst. Francais Petrole, 37, 1982, 1, p. 3-17. 